\title{
$>0$ conceito de inautenticidade no pensamento heideggeriano de Ser e tempo
}

$>$ The concept of inauthenticity in the heideggerian thought of Being and

\author{
por Rafael Ribeiro Almeida \\ Graduando em Filosofia na Universidade Estadual de Santa Cruz (UESC). \\ E-mail: estudosrafael@gmail.com. ORCID: 0000-0002-5040-878X. \\ por Rogério Tolfo \\ Professor Doutor da Universidade Estadual de Santa Cruz (UESC). \\ E-mail: tolfo72@gmail.com. ORCID: 0000-0003-1807-190X.
}

\section{Resumo}

Neste artigo, pretende-se explicitar o conceito heideggeriano de inautenticidade tal como desenvolvido em Ser e tempo de Martin Heidegger. Ao trazer à tona o sentido de poder-ser inautêntico, em contraste com poder-ser todo em sentido autêntico do Dasein, nota-se inicialmente que não se trata de uma relação de hierarquia em termos de superior e inferior, no sentido de que um indica uma existência melhor e o outro não, isto é, não implica em uma valoração moral, axiológica ou mesmo ontológica. Antes, estes conceitos se referem a determinados modos de existir, que dizem respeito a possibilidades de ser-no-mundo, nas quais o Dasein sempre tem compreensão. Ao cabo, destaca-se que o Dasein nunca está irrecuperavelmente perdido na inautenticidade, pois, em última instância, o ser-no-mundo - mesmo inautêntico - é, em essência, cuidado.

Palavras-chave: Inautenticidade. Dasein. Decadência. Compreensão. Cuidado.

\begin{abstract}
In this paper, we will attempt to explain the concept of inauthenticity in the Heideggerian thought of Being and time (1927). When we give an explicative summary of the meaning of inauthentic can-to-be, in contrast with Dasein's authentic potentiality-for-being-a-whole (own can-to-be), we can see, then, that it is not a relationship of hierarchy between upper and lower - that is, these concepts do not indicate better or worse existence. Before that, however, both concepts are limited at indicating ways of existing, which contain possibilities of being-in-the-world, where the Dasein always has understanding. After all, we will highlight that Dasein is never definitely lost (mired) in inauthenticity, however, being-in-the-world - even inauthentic - is essentially care.
\end{abstract}

Keywords: Inautenticity. Dasein. Decay. Understanding. Care. 
Nossos agradecimentos aos pareceristas anônimos pelas sugestões e observações a partir das quais aprimoramos este artigo em sua finalização.

\section{Considerações iniciais}

O problema fundamental de Ser e tempo coincide com o problema fundamental da ontologia, segundo Martin Heidegger, qual seja: a elaboração e explicitação da questão do sentido do ser. Nota-se o objetivo diretriz do filósofo alemão com seu tratado de 1927, ao se recorrer à primeira página de sua obra, a saber: uma citação de O Sofista, de Platão: "pois é evidente que de há muito sabeis o que propriamente quereis designar quando empregais a expressão 'ente'. Outrora, também nós julgávamos saber, agora, porém, caímos em aporia"1.

Essa passagem constata, por um lado, que a questão do ser jaz sem solução na filosofia platônica, e - por que não? -, de modo geral no pensamento grego. Porém, ao mesmo tempo, essa passagem nos indica de alguma forma que a aporia em relação ao significado do termo "ente" também persiste, de maneira aguda, até os nossos dias. Desde o mundo grego (que identifica ser com presença constante), cujo paradigma de pensamento é apropriado e cristianizado pelo contexto medieval, até a época propriamente moderna (na qual o ser do ente humano é dogmaticamente reduzido à dicotomia sujeito-objeto), a questão do significado do ser do ente não foi resolvida no interior da história da filosofia ocidental. Assim, abrir o tratado de Ser e tempo por uma citação de Platão é, de certa forma, um modo de Martin Heidegger indicar que seu problema diretriz a ser tematizado é um problema de origem, origem no sentido de que surge juntamente com a própria história da filosofia ocidental e que, até agora, continua sinalizando incessantemente por uma tematização.

Todavia, visto que o problema do ser permanece em aporia desde os primórdios da filosofia ocidental, no que consiste, então, a particularidade da

\footnotetext{
${ }^{1}$ Martin Heidegger, Ser e tempo - parte I, 1988, p. 24.
} 
abordagem heideggeriana dessa questão? Qual é a característica distinta da obra Ser e tempo acerca do sentido do ser?

O jovem Heidegger observa a necessidade de colocar em questão: como é o ser e não o que é o ser. O corolário disso é que o autor procura no ser do ente humano não mais uma essência fixa ou substância distintiva - conforme se deu em inúmeras definições na história do pensamento ocidental -, mas, isto sim, seus possíveis modos de ser em termos de possibilidades existenciais do ser-aí humano. Assim sendo, ao longo dos 83 parágrafos de seu tratado incompleto, Heidegger procura distinguir os dois modos fundamentais de ser-no-mundo: o modo autêntico e o modo inautêntico².

Contudo, não raras são as vezes em que autenticidade e inautenticidade são interpretadas enquanto existência superior e existência inferior, no sentido de que uma é melhor que a outra. Deste modo, nossa pretensão reside em destacar que autenticidade e inautenticidade não equivalem a existir, mas, isto sim, indicam o modo de existir. Neste sentido, o conceito de inautenticidade, em Ser e tempo, não é desenvolvido por Heidegger em termos de hierarquizá-lo nem aquém nem além do modo autêntico de ser-no-mundo. $O$ poder-ser inautêntico e o poder-ser autêntico dizem respeito aos modos de ser-no-mundo: um modo em que o Dasein se perde no impessoal, e outro no qual ele se coloca diante de seu

\footnotetext{
${ }^{2}$ É importante que se faça um breve esclarecimento sobre a tradução do termo Eigentlichkeit, considerando que o tema é demasiado controverso. Pode-se traduzir por propriedade ou autenticidade. De fato, a expressão alemã corresponderia a propriedade, enquanto o termo autenticidade corresponderia a Echtheit. Aqui optou-se por traduzir o termo Eigentlichkeit por autenticidade seguindo a linha argumentativa de Inwood no Dicionário Heidegger: "Desta forma, eigentlich, quando usado como termo técnico, está próximo de 'autêntico', que vem do grego autos, 'si mesmo' e significava originalmente 'feito por suas próprias mãos', 'garantido por confiança'. Heidegger usa em geral uneigentlich, 'não literal(mente), figurativo(amente)', como o contrário de eigentlich. Ele também usa Eigentlichkeit, 'autenticidade', e forja Uneigentilchkeit, 'inautenticidade'" (Michael Inwood, Dicionário Heidegger, 2002, p. 11). Além destes, outros termos também são controversos, por exemplo Das Man: eles, impessoal e a gente; Zuhandenheit: manualidade, disponibilidade e utilizabilidade. No caso da tradução de Fausto Castilho, que tem sido uma alternativa, há problemas como o dos termos "existencial" e "existenciário", o que torna difícil o consenso quanto ao uso de apenas uma tradução, ou melhor, do uso de termos de uma única tradução ser aceita por todos os especialistas. Outro problema é o acesso ainda restrito da tradução (bilíngue) de Castilho a estudantes que travam um primeiro contato com a obra de Martin Heidegger, embora sua leitura possa ser mais agradável e mais clara.
} 
poder-ser-si-mesmo. O modo de ser inautêntico do ser-aí, neste sentido, não é valorado por Heidegger como o mal do qual devemos escapar - e tampouco a autenticidade está como bem para o qual devemos tender -, antes, porém, tratase de uma possibilidade de ser, na qual o Dasein ainda tem compreensão [Verstehen] e que, mesmo inautêntico, continua a ser, em essência, cuidado [Sorge].

Assim sendo, o objetivo fundamental do presente artigo consiste em examinar o modo inautêntico de ser-no-mundo. Inicialmente, neste trabalho explicita-se o conceito de decadência [Verfallen], cujas características são tentação, tranquilidade, alienação e aprisionamento de si mesmo. Decadência indica que, de início e na maioria das vezes, o Dasein perde-se de si mesmo ao se afundar na ocupação [Bersogen]. Quer dizer, o Dasein caiu de si mesmo e de-caiu no mundo das ocupações e passa a compreender a si mesmo (o mundo e aos outros) em função apenas destas ocupações. Em seguida, explicita-se o sentido heideggeriano de publicidade [Öffentlichkeit] do impessoal (cujos elementos característicos são falatório, curiosidade e ambiguidade). Nela, a possibilidade de ser-próprio do Dasein é tomada pelos outros, na medida em que se dá o domínio da impessoalidade. O impessoal, quer dizer, os outros, retira do ser-no-mundo a responsabilidade de ter que assumir seu próprio ser. O Dasein não é ele próprio e sim os outros que lhe tomam o ser. Depois disso, pretende-se evidenciar que autenticidade e inautenticidade são duas possibilidades, modos de ser-no-mundo que, enquanto tais, não estabelecem entre si uma relação de hierarquia em termos de melhor ou pior. Destaca-se que a existência inautêntica não corresponde a uma existência "menor", mas sim a um modo de existir. O Dasein (in)autêntico sempre tem e é compreensão [Verstehen]. Além disso, o Dasein nunca está irrecuperavelmente perdido na inautenticidade, pois, em última instância, o ser-no-mundo - mesmo inautêntico - é, em essência, cuidado [Sorge]. Ou seja: ele possui como estrutura mais originária e primária a relação cuidadosa com seu ser. 


\section{De-cadência}

Com efeito, somente ao Dasein há a possibilidade de ser (in)autêntico. Todos os demais elementos que Ser e tempo assinala como (in)autênticos - morte, temporalidade, compreensão, discurso, e outros - o são em relação tão somente à (in)autenticidade do Dasein. A possibilidade de o Dasein ser autêntico ou inautêntico se enraíza em uma das ideias centrais de Ser e tempo: "O Dasein é o ente que sempre eu mesmo sou, o ser é sempre meu"3. Ou seja: o ser, que está sempre em jogo (em sendo), é sempre meu, de modo que já sempre foi decidido de que modo é meu: "Sendo porém sempremeu, o poder-ser é livre para a propriedade e a impropriedade"4 . Ser sempre meu significa estar entregue à responsabilidade de minha própria abertura [Erschlossenheit] existencial. Neste sentido, ser sempre meu é o que possibilita, por sua vez, a autenticidade ou inautenticidade, na medida em que posso compreendê-lo ou perdê-lo.

Quer dizer, o Dasein não possui uma "natureza" inicial (com um conteúdo ou substância fixa tal qual uma mesa, casa, árvore), mas, isto sim, está entregue à responsabilidade de sua própria projeção, de modo que sua essência - na medida em que se possa falar dela - equivale a estar sempre em sendo: "A 'essência' do Dasein está em sua existência"5. Neste sentido, pode assumir seu ser de modo exclusivamente próprio, compreendendo a si mesmo e apoderando-se de si mesmo, como assinala Dermot Moran: "momentos autênticos são aqueles em que nós estamos mais em casa com nós mesmos, unicamente com nós mesmos"6. Ou, ao invés disso, o Dasein pode abrir seu ser de forma deficiente, quer dizer: não se apoderando de si mesmo. Segundo Rüdiger Safranski, de início e na maior parte das vezes, o Dasein existe nesta condição: "A inautenticidade seria a forma original de nosso Dasein, e não apenas no sentido do (onticamente) habitual, mas também do ontológico"7.

\footnotetext{
${ }^{3}$ Martin Heidegger, Op. Cit., 1988, p. 165.

${ }^{4}$ Idem, Ser e tempo - parte II, 2005, p. 11.

${ }^{5}$ Idem, Op. Cit., 1988, p. 77.

${ }^{6}$ Dermot Moran, Introduction to phenomenology, 2000, p. 240.

${ }^{7}$ Rüdiger Safranski, Heidegger - um mestre da Alemanha entre o bem e o mal, 2000, p. 203.
} 
Em Ser e tempo - nas duas divisões mas sobretudo na primeira -, o autor vale-se repetidas vezes da fórmula de início e na maior parte das vezes: "Na maioria das vezes e antes de tudo, o Dasein é absorvido por seu mundo"8; "De início, o Dasein é impessoal e, na maior parte das vezes, assim permanece" ${ }^{\prime \prime}$. Longe de ser mera eloquência, essa expressão de fato nos evidencia algo a se investigar: inicialmente e na maioria das vezes se refere à cotidianidade mediana do Dasein (que nesta condição ainda não ganhou a si mesmo) a qual significa a existência no modo da inautenticidade.

É verdade que Heidegger sugere algumas vezes que, uma vez na cotidianidade mediana, o Dasein não é nem autêntico nem inautêntico, mas sim indiferente ou indiferença [Indifferenz $]^{10}$. Cotidianidade mediana "é, antes, um modo de ser do Dasein"11, e mais precisamente, o modo mais próximo pelo qual ele se dá: neste sentido se trata de uma indiferença da cotidianidade, em termos de sua indeterminação. E isso significa que, na primeira seção de Ser e tempo, a análise existencial que Heidegger emprega acerca do Dasein tem como ponto de partida a indiferença da cotidianidade, no sentido da análise da existência em sua indeterminação: "Em seu ponto de partida, a analítica não escolheu como tema uma possibilidade de existência do Dasein determinado e privilegiado. Mas orientou-se por um modo de existir mediano e não surpreendente"12.

Ainda que Heidegger expresse que o Dasein cotidiano não necessariamente corresponda ao modo de ser inautêntico ${ }^{13}$ (tal como é o ponto de partida de sua analítica na divisão I), em última instância, porém, de início e na maioria das vezes, o Dasein, em sendo, diz respeito a seu modo de inautencidade - Heidegger em seu texto O Conceito de tempo, de 1924 diz "Em média, a explicação do ser-aí é

\footnotetext{
${ }^{8}$ Martin Heidegger, Op. Cit., 1988, p. 164.

${ }^{9}$ Ibidem, p. 182.

${ }^{10}$ Martin Heidegger, Op. Cit., 1988, p. 78-79.

${ }^{11}$ Ibidem, p. 87

${ }^{12}$ Idem, Ser e tempo II, 2005, p. 172.

${ }^{13}$ Por exemplo: "Esta indiferença da cotidianidade do Dasein não é um nada negativo mas um caráter fenomenal positivo deste ente. [...] Denominamos esta indiferença cotidiana do Dasein de medianidade" Martin Heidegger, Op. Cit., 1988, p. 79.
} 
dominada pela cotidianidade"14. Conforme assinala o Dicionário Heidegger: "Embora a cotidianidade comece como uma condição neutra, ela acaba tornandose um estado de decadência e inautenticidade ${ }^{m 15}$. Ou, dito de modo literal:

Primordialmente, porém, a expressão cotidianidade indica um determinado modo de existência que domina o Dasein em seu 'tempo de vida'. No decorrer das análises precedentes, com frequência nos valemos da expressão 'de início e na maior parte das vezes'. 'De início' significa o modo em que o Dasein 'se revela' na convivência da public-idade, mesmo que, existenciariamente, ele tenha 'no fundo' superado a cotidianidade. 'Na maior parte das vezes' significa o modo em que o Dasein nem sempre, mas 'via de regra', se mostra para todo mundo. ${ }^{16}$

Quer dizer, a expressão em questão, no limite, diz respeito a uma possibilidade fundamental de ser da cotidianidade do Dasein: a perda de si próprio (que na citação acima está expressa pelo termo publicidade, conforme veremos adiante).

O Dasein, no entanto, não perde a si mesmo tal como se perde um guardachuva. Segundo Heidegger, ele se perde na ocupação [Besorgen] - trata-se dos modos do Dasein de lidar no mundo, o fazer com alguma coisa, produzir alguma coisa, empreender, pesquisar, construir, consertar, por exemplo. Tais modos de ocupação no manuseio e uso contemplam as relações que o Dasein trava apenas com o modo de ser dos entes disponíveis [Zuhandenheit] ${ }^{17}$, através de um conhecimento "prático", chamado por Heidegger de circunvisão [Umsicht]; segundo Günter Figal: "'Ocupação' é aqui um termo que designa um 'modo de ser' do 'ser-no-mundo', a saber, todas as maneiras de comportar-se que apontam para uma lida com um ente, que não se mostra como 'ser-aí'118. No entanto, o problema apontado por Heidegger, por assim dizer, não reside propriamente no fato de o Dasein ser-junto-ao-mundo (ocupação), inclusive porque o Dasein já sempre está

\footnotetext{
${ }^{14}$ Martin Heidegger, O Conceito de tempo, 1997b, p. 21.

${ }^{15}$ Michael Inwood, Op. Cit., 2002, p. 12.

${ }^{16}$ Martin Heidegger, Op. Cit., 2005, p. 173.

17 O termo alemão é traduzido de diferentes formas tais como manualidade, na tradução de Márcia Cavalcante. Disponibilidade ou disponível à mão (readiness-to-hand) na tradução de Macquarrie and Robinson (Martin Heidegger, Being and Time, 1962). Disponivel à mão (estar a la mano) na tradução de Rivera (Martin Heidegger, Ser y Tiempo, 1997a).

${ }^{18}$ Günter Figal, Martin Heidegger: fenomenologia da liberdade, 2005, p. 73.
} 
nesse modo (ao se abrir uma porta, por exemplo, faz-se uso do trinco; ou quando se tenta utilizar uma caneta, mas sua tinta acabou) - neste caso vê-se sua importunidade [Aufdringlichkeit] ${ }^{19}$. A questão colocada pelo autor é que o Dasein perde a si mesmo ao estar totalmente absorvido pelo mundo da ocupação, no qual, neste sentido, passa a compreender a si mesmo (o mundo e aos outros) em função apenas destas ocupações: "A cotidianidade toma o Dasein como um manual de ocupação, ou seja, como gerência e cálculo. A 'vida' é um 'negócio', independentemente se ela paga ou não o seu preço" ${ }^{20}$. Com efeito, Heidegger sintetiza melhor esta ideia ao trazer à tona o sentido de decadência [Verfallen].

O termo decadência não possui valoração moral de "queda" de um estado mais puro e tampouco "exprime qualquer avaliação negativa"21. O termo diz respeito ao modo de ser-no-mundo cotidiano. Decadência está como fenômeno ontológico-existencial que, enquanto tal, diz respeito ao modo específico de abertura do Dasein em sua cotidianidade, no qual ele foge de si mesmo ao se deixar absorver pelas ocupações. De início e na maior parte das vezes, o Dasein está junto e no próprio contexto de ocupação, e é justamente neste empenhar-se das ocupações que reside o sentido do conceito de decadência.

De acordo com Ser e tempo, a decadência enquanto modo de ser-no-mundo cotidiano possui determinadas características: tentação, tranquilidade, alienação e aprisionamento em si mesmo. Tentação, em primeiro lugar, pois o próprio Dasein traz em si mesmo a tentação de de-cair - ser-no-mundo já é, em si mesmo, tentador. Com isso, Heidegger sinaliza que é o próprio Dasein que oferece constantemente a si mesmo a tentação de perder a si mesmo, ou seja, pertence ao próprio Dasein a tendência de se encobrir e fugir de si mesmo. O Dasein mantémse preso à sua decadência devido a sua própria constituição ontológica (de tendência) tentadora. Neste sentido, nota-se a segunda característica da

\footnotetext{
${ }^{19}$ Neste caso, o disponível específico tem o curso normal de suas ordens impedido ou bloqueado decorrente de uma falta, desdobrando, então, o caráter de inutilidade. A importunidade refere-se ao deparar-se com o que falta: uma caneta sem tinta.

${ }^{20}$ Martin Heidegger, Op. Cit., 2005, p. 78.

${ }^{21}$ Idem, Ser e tempo I, 1988, p. 236.
} 
decadência: o Dasein se mantém tranquilo. Essa característica designa a pretensão que o Dasein tem de "dirigir" sua existência toda ela de forma impessoal (considerando-a, porém, como autêntica): isso o tranquiliza no sentido de que lhe assegura que tudo "está em ordem". "O ser-no-mundo da de-cadência é, em si mesmo, tanto tentador como tranquilizante"22. Essa tranquilidade, no entanto, não oferece serenidade ou calma (como o termo traduzido pode sugerir), mas, pelo contrário, promove desenfreadas agitações. A tranquilidade tentadora não desemboca em repouso e sim aumenta e intensifica a decadência. Tais agitações estão ligadas à curiosidade na qual há voracidade insaciável do Dasein por novidades, isto é, o movimento de espraiar a "visão" do Dasein para todas as direções, os contextos e os sentidos, todos aleatoriamente selecionados e que resultam, por excelência, em inquietação e dispersão.

Seguindo o raciocínio, o Dasein desse modo dirige-se a uma alienação do seu próprio poder-ser em sentido próprio. "O ser-no-mundo da de-cadência, tentador e tranquilizante é também alienante"23. Alienação não em termos de se encontrar, definitivamente, arrancado de seu próprio ser, mas sim no sentido de que a alienação fecha/encobre para o Dasein o projeto de existência autêntica como sua possibilidade. Assim, a alienação força (coage) o Dasein à inautenticidade, ou seja, ela o aprisiona em si mesmo. Essa última característica indica que o Dasein está aprisionado em si mesmo na medida em que a decadência encobre para ele a possibilidade de seu poder-ser próprio, sua propriedade, forçando, então, o Dasein a se encerrar somente na impropriedade. Posto isso, estes são os fenômenos que caracterizam o modo de ser específico da decadência: tentação, tranquilidade, alienação e aprisionamento. Neste sentido, evidencia-se mais precisamente a significação da decadência: na decadência, o Dasein caiu de si mesmo e de-caiu no mundo das ocupações, no sentido de que ele perdeu-se a si mesmo ao estar totalmente absorvido pelo mundo das ocupações.

\footnotetext{
${ }^{22}$ Martin Heidegger, Op. Cit., 1988, p. 239.

${ }^{23}$ Ibidem, p. 239.
} 


\section{Publicidade do impessoal: falatório, curiosidade e ambiguidade}

Com efeito, pretende-se aqui evidenciar a perdição do Dasein no co-Dasein dos outros no modo da publicidade do impessoal.

Neste ponto, com efeito, reside outra ideia-chave para se apreender o sentido de inautenticidade do Dasein: o de perder-se na publicidade do impessoal. "A inautenticidade está frequentemente associada com o impessoal"24.

A partir de um mundo circundante [Umwelt ${ }^{25}$, os "outros" vem ao encontro do Dasein, trazendo à tona, por conseguinte, o mundo da publicidade [Öffentlichkeit]. Publicidade diz respeito à condição de ser público, de estar aberto para todos. A partir do mundo em que o Dasein se conserva empenhado em ocupações orientadas pela circunvisão (o fabricar, o produzir, o empreender, o alugar, o construir, o consertar, etc), o Dasein perde-se, de início e na maior parte das vezes, na publicidade. Nela, a possibilidade de ser-próprio do Dasein é tomada pelos "outros", na medida em que se dá o domínio da impessoalidade. O impessoal é todos e ninguém - os "outros": "O impessoal encontra-se em toda parte"26; "Todo mundo é outro e ninguém é si próprio"27. O impessoal, quer dizer, os "outros", retira do ser-no-mundo a responsabilidade de ter que assumir seu próprio ser. $O$ Dasein não é ele próprio e sim os outros que lhe tomam o ser. As possibilidades

\footnotetext{
${ }^{24}$ Michael Inwood, Op. Cit., 2002, p. 12.

${ }^{25}$ Mundo circundante é contexto, e contexto com-partilhado no qual se libera os outros Dasein os quais vem ao encontro nesse mundo. Por exemplo, um contexto de produção de canetas: para se produzir uma caneta faz-se necessário articular toda uma conjuntura instrumental pertinente a este ente. Com isso, também vem ao encontro outros entes - estes, porém, existentes - para os quais a "obra" se destina ou mesmo demanda: junto com o material empregado, também vem ao encontro o seu produtor e/ou fornecedor; e mais, o local no qual se produz propriamente o objeto em questão, mostra-se como local que pertence a alguém, alugado a outrem; a caneta fabricada é vendida em tal lugar que pertence a tal comerciante; ao fabricar tal objeto, visa-se para qual tipo de pessoa pretende vender... e assim por diante. Heidegger frisa: "O próprio Dasein, bem como o co-Dasein dos outros, vem ao encontro, antes de tudo e na maior parte das vezes, a partir do mundo compartilhado nas ocupações do mundo circundante" (Martin Heidegger, Op. Cit., 1988, p. 178).

${ }^{26}$ Ibidem, p. 180.

${ }^{27}$ Ibidem, p. 181.
} 
cotidianas de ser do Dasein são, por assim dizer, ofuscadas pelo lugar comum dos outros.

Segundo Heidegger: "O impessoal é um existencial e, enquanto fenômeno originário, pertence à constituição positiva do Dasein"28. O impessoal é um fenômeno originário e pertence existencialmente à estrutura do Dasein na medida em que, independente do quadro histórico, político ou social, todo Dasein está, de início, junto ao "A-gente". Em condição elementar e originária, o impessoal sela e demarca a primeira interpretação do Dasein (e do mundo). Primariamente, o Dasein se acha disperso no "nós", precisando, então, encontrar a si mesmo. Nota-se, então, que, de início, o Dasein está de fato no contexto comum e abstrato da impessoalidade; de início, "eu" não sou "eu" em termos de propriamente ser si mesmo e sim sou os outros nos moldes do impessoal; de início, "eu sou dado" a mim mesmo a partir e como impessoal.

No domínio da publicidade, a especificidade do modo de ser do Dasein apaga-se na impessoalidade. "Este conviver dissolve inteiramente o próprio Dasein no modo de ser dos 'outros' e isso de tal maneira que os outros desaparecem ainda mais em sua possibilidade de diferença e expressão"29. A singularidade de cada Dasein é pulverizada na medida em que a impessoalidade se faz presente de forma dominadora, no sentido de totalizante. O domínio da impessoalidade consiste, por exemplo, na utilização diária que o trabalhador faz do ônibus, no uso comum dos meios de comunicação, tais como a televisão, jornal, internet, e até mesmo no próprio entretenimento em que homens e mulheres buscam se divertir. E mais: a singularidade do Dasein é anulada, por exemplo, quando o modo em que o ente humano critica a política passa a estar em conformidade com como impessoalmente critica-se a política; ou quando ele considera revoltante determinada situação conforme o que impessoalmente se considera revoltante: "O impessoal sempre conhece, discute, favorece, combate, mantém e esquece, primordialmente, na perspectiva daquilo que se empreende e

\footnotetext{
${ }^{28}$ Ibidem, p. 182.

${ }^{29}$ Martin Heidegger, Op. Cit., 1988, p. 179.
} 
daí 'emerge" 30 . Em suma, cada um é "sujeito-massa", já que cada um age e avalia conforme impessoalmente se age e se avalia - não há singularidade e sim uniformidade. É o impessoal quem sentencia o que, na medianidade, tem valor ou não, tem sucesso ou não, tem importância ou não, e, além disso, o impessoal vigia e controla qualquer possibilidade de exceção. "Tudo que é originário se vê, da noite para o dia, nivelado como algo de há muito conhecido. O que se conquista com muita luta, torna-se banal. Todo segredo perde sua força" ${ }^{\text {"1 }}$. Numa palavra, toda singularidade é esmagada pelo domínio da impessoalidade.

Por último, Heidegger indaga-se: "Será que esse modo de ser [impessoal] possui uma disposição própria e específica, uma compreensão, um discurso e uma interpretação especiais?" 32 . Quer dizer, o autor propõe-se a explicitar a abertura do impessoal, o que significa nesse caso evidenciar o modo de ser cotidiano do discurso, o modo de ser cotidiano da visão e o modo de ser cotidiano da interpretação. Neste sentido, três são os elementos característicos da abertura do impessoal: falatório [Gerede], curiosidade [Neugier] e ambiguidade [Zweideutigkeit].

Falatório, que não deve ser tomado em um sentido pejorativo, constitui o modo de ser da compreensão e interpretação do Dasein cotidiano. Falatório designa o discurso pronunciado pelo Dasein que é compreendido amplamente, sem que para isso, porém, o ouvinte compreenda originariamente do que trata propriamente o discurso. Ou seja, nesse caso a tentativa de uma compreensão autêntica é deixada de lado e a compreensão banal é tomada como profunda. Nesse sentido, "tanto a escuta quanto a compreensão já se colaram previamente no que foi falado no falatório"33. Em uma comunicação assim disposta, o que é "compartilhado" é a fala comum, é a fala que todos falam: a conversa fiada, os boatos, a tagarelice, os clichês. O falado no falatório está no seguinte sentido, "isso é assim como é porque disso falam assim", e desse modo repete-se e passa-se

\footnotetext{
${ }^{30}$ Martin Heidegger Op. Cit., 2005, p. 194.

${ }^{31}$ Martin Heidegger, Op. Cit., 1988, p. 180.

${ }^{32}$ Ibidem, p. 226.

${ }^{33}$ Ibidem, p. 228.
} 
adiante a fala, sedimentando cada vez mais sua falta de solidez e fundamento até que, em última instância, não se diferencie mais o que é originário e o que é mera repetição. "E mais ainda, a própria compreensão mediana não tolera tal distinção, pois não necessita dela já que tudo compreende" ${ }^{\prime 34}$. Dessa forma, nota-se que o falatório é a possibilidade por excelência de se compreender tudo sem se ter rigorosamente apropriado o que se compreendeu, quer dizer, nessa possibilidade pode-se saber de tudo do qual nada é excluído e, ao mesmo tempo, dispensar a árdua tarefa de uma compreensão e discussão autênticas. "É dessa maneira que nós aprendemos e conhecemos muitas coisas e não poucas jamais conseguem ultrapassar uma tal compreensão mediana" ${ }^{\prime 35}$. O Dasein nesse modo tende para uma crescente falta de solidez e permanece assim sob a proteção da autoevidência daquilo que todos sabem, todos compreendem, todos repetem.

Indo além, no domínio da publicidade dá-se aquilo que Heidegger tratou por curiosidade [Neugier]. Curiosidade diz respeito à "visão" do Dasein que, sempre atento às novas informações e novidades da "moda", distrai e desfocaliza o Dasein empurrando-o sempre para possibilidades superficiais, "imediatizantes" e arbitrárias, de modo que nenhuma sacie sua curiosidade. Curiosidade designa a voracidade insaciável do Dasein por inovações (que na verdade, porém, são todas iguais e uniformes), despersonalizando e descaracterizando, então, qualquer projeto de existência autêntica. Ademais:

A curiosidade liberada, porém, ocupa-se em ver, não para compreender o que vê, ou seja, para chegar a ele num ser, mas apenas [sic] para ver. Ela busca apenas o novo a fim de, por ele renovada, pular para uma outra novidade. ${ }^{36}$

Quer dizer, o Dasein curioso não se interessa por se transformar e se diferenciar em tais novidades, mas o que importa é o próprio movimento de espraiar sua visão para todas as direções, para todos os contextos e para todos os sentidos, todos aleatoriamente selecionados e que resultam, por excelência, em

\footnotetext{
${ }^{34}$ Martin Heidegger, Op. Cit., 1988, p. 228.

${ }^{35}$ Ibidem, p. 229.

${ }^{36}$ Ibidem, p. 223.
} 
inquietação e dispersão - ao buscar sempre novas direções, contextos e sentidos, o Dasein acaba mesmo por encontrar-se desenraizados de todos. A curiosidade não se limita a se focar em um tipo especial de projeto, sua característica principal, diga-se de passagem, reside em estar impermanentemente em uma determinada escolha existencial: escolhe-se estar assim, mas logo pula-se para estar assim, para depois estar de outra forma e depois estar de mais outra forma. Na curiosidade, o Dasein projeta-se em todas as possibilidades e por isso mesmo em nenhuma.

Em vista disso, articula-se a curiosidade, a que nada se esquiva, e o falatório, que tudo compreende:

O falatório abre para o Dasein, numa compreensão, o ser para o seu mundo, para os outros e para consigo mesmo, mas de maneira a que esse ser para... conserve o modo de uma oscilação sem solidez. A curiosidade abre toda e qualquer coisa de maneira a que o ser-em esteja em toda parte e em parte alguma. ${ }^{37}$

Falatório e curiosidade, juntos eles "dão ao Dasein, que assim existe, a garantia de 'uma vida cheia de vida', pretensamente autêntica. Com esta pretensão, porém, prossegue Heidegger, mostra-se um terceiro fenômeno característico da abertura do Dasein cotidiano"38, a saber: a ambiguidade.

Na convivência cotidiana, vem ao encontro simultaneamente tanto o que é acessível à abertura primordial do Dasein quanto aquilo de que todos podem dizer qualquer coisa, de modo que não seja mais possível distinguir um do outro: eis a ambiguidade. Aquilo que parece ter sido originariamente compreendido, rigorosamente apropriado e autenticamente discutido, no fundo, não foi. Ou, inverso, aquilo que parece não ter sido compreendido, apropriado e discutido quando, no fundo, já foi. De acordo com Stegmüller: "A ambiguidade refere-se ao triste fato de que não dispomos de nenhum critério para poder distinguir no mundo o autêntico do inautêntico"39. Essa ambiguidade se consolida na própria compreensão do poder-ser do Dasein, quer dizer: o poder-ser, o não poder-ser e o

\footnotetext{
${ }^{37}$ Martin Heidegger, Op. Cit., 1988, p. 238.

${ }^{38}$ Ibidem, p. 233.

${ }^{39}$ Wolfgang Stegmüller, A filosofia contemporânea: introdução crítica, 1977, p. 142.
} 
como poder-ser do Dasein encontram-se já inserido no seio dessa ambiguidade para a qual ele foi lançado. Com efeito, "todo mundo" conhece e discute o que se dá ("todo mundo" sabe o que se deve fazer na política), do mesmo modo "todo mundo" já sabe discorrer sobre o que ainda vai acontecer e sobre o que não vai acontecer, e sobre o que "propriamente" deve acontecer: tudo é compreendido, tudo é entendido, tudo é apreendido - esse "é o modo mais traiçoeiro em que a ambiguidade propicia ao Dasein possibilidades, a fim de sufocar-lhes a força"40. Mover-se na ambiguidade significa estar na linha tênue entre o que de fato se deu e o que impessoalmente se deu, ou seja, estar na sutil e silenciosa fronteira entre a hegemonia e a falta de hegemonia do falatório e da curiosidade. Desse modo, o Dasein, no impessoal, é e está sempre "atado" a esse modo ambíguo, ou seja, "atado" entre a abertura da publicidade na convivência - onde o falatório e a curiosidade controlam e ditam o tom - e a abertura compreensiva em possibilidades ontológicas autênticas. "Sob a máscara da composição, o que realmente acontece é a oposição entre um e outro"41.

Além disso, deve-se ressaltar a importantíssima observação de Ser e tempo segundo a qual a ambiguidade não é, pois, o resultado deliberado e maniqueísta de um Dasein singular, ou mesmo o fruto de deturpação e distorção de um agente. Assim, Heidegger não pretende com isso desenvolver uma análise moralizante da ambiguidade, valorando-a como "boa" ou "má", ou mesmo realizar uma filosofia da crítica da cultura, apontando a ambiguidade como de ordem social. Antes, porém, ao desenvolver essa análise Ser e tempo tem um propósito somente e tão somente ontológico: "Os fenômenos do falatório, da curiosidade e da ambiguidade foram explicitados de maneira a revelar entres eles mesmos um nexo ontológico"42. Conclui-se, assim: a ambiguidade é estrutura ontológica.

\footnotetext{
${ }^{40}$ Martin Heidegger, Op. Cit., 1988, p. 234.

${ }^{41}$ Ibidem, p. 236.

42 Ibidem, p. 236.
} 


\title{
4. Autenticidade e inautenticidade: duas possibilidades de modos de ser-no- mundo
}

Com efeito, faz-se necessário, ainda em relação à cunhagem da noção de inautenticidade, sinalizar um oportuno adendo no sentido de não hierarquizá-la nem aquém nem além de qualquer outro modo de ser do Dasein. De saída, vale uma observação de Marco Casanova:

\begin{abstract}
É preciso tomar um certo cuidado para não concluirmos aqui apressadamente algo de que Heidegger procura incessantemente escapar. Ao ouvirmos expressões como 'ditadura do impessoal', 'impropriedade', 'decadência', 'falatório', 'ambiguidade' e 'curiosidade', expressões correntes na concepção heideggeriana do modo de o ser-aí se encontrar de início e na maioria das vezes imerso no mundo fático que é o dele, tendemos a pensar essas expressões em uma chave antropológico-moralizante e a ler Ser e tempo, por conseguinte, como se o que estivesse em questão na obra fosse determinar o modo como precisamos conquistar o nosso si-mesmo, como se o texto levantasse de maneira sistemática a questão de saber como o ser-aí singular se transforma no que ele verdadeiramente é. ${ }^{43}$
\end{abstract}

Quer dizer, de acordo com Ser e tempo, conforme procurou-se evidenciar, de início e na maioria das vezes o ser-no-mundo encontra-se completamente absorvido pelo mundo das ocupações e pelo co-Dasein dos outros no modo da publicidade do impessoal, e isso equivale a estar no modo da inautenticidade. Isso não significa, como observa Casanova, que Heidegger pretendia com Ser e tempo indicar que precisamos alcançar a autenticidade tal qual um bem para o qual devemos tender, como se o filósofo alemão realizasse uma demarcação da sua noção de inautenticidade a fim de inferiorizá-la ou valorá-la como o "mal" do qual devemos escapar. De acordo com Rüdiger Safranski, Ser e tempo não é um tratado em que Heidegger lança-se no afã de descrever um ideal de Dasein: "Heidegger não descreve um ideal de existência mas apenas os dispositivos existenciais"44.

E, além disso, Charles Guignon destaca que mesmo o ser-aí em sua existência autêntica não significa que ele esteja destacado (no sentido de uma existência "melhor") do mundo cotidiano:

\footnotetext{
${ }^{43}$ Marco Casanova, Compreender Heidegger, 2009, p. 103, grifo nosso.

${ }^{44}$ Rüdiger Safranski, Op. Cit., 2000, p. 172.
} 
De fato, uma vez que nossas próprias histórias de vida são inseparáveis do amplo texto de um mundo que compartilhamos entre nós, a autenticidade não pode ser nada mais que uma forma completa e enriquecida de participação no contexto público. ${ }^{45}$

De fato, assumir um modo completo e enriquecido de participação no contexto de sentido não equivale a ter uma existência "superior". Neste mesmo sentido, afirmar que o ente que nós mesmos somos é inautêntico não é o mesmo que ser "menos" humano, conforme diz Michael Inwood em seu livro Heidegger: "O Dasein é por vezes autêntico e outras vezes inautêntico. Heidegger por acaso sugere que só o autêntico Dasein é de fato Dasein, é de fato ser humano? Esse Dasein inautêntico não é propriamente humano? Não"46.

Antes, porém, os modos autêntico e inautêntico são por excelência duas possibilidades de ser; neste raciocínio Jean-Paul Resweber destaca:

Não entendamos as categorias de autenticidade e de inautenticidade segundo critérios de ordem moral. A existência inautêntica tem a sua linguagem e a sua lei próprias: ela não é uma simples aparência do ser mas uma dimensão real da ek-sistência. Nunca é, pois, superada pela conversão à existência autêntica. $O$ homem vive constantemente na encruzilhada da autenticidade e da inautenticidade; os cuidados cotidianos ocultam-lhe sempre o seu Cuidado fundamental; o espetáculo do mundo tende a fazerlhe esquecer o seu ser-no-mundo; o medo frente a um sendo particular ou o sendo na totalidade mascara-lhe a angústia do seu ser perante a presença do Ser. ${ }^{47}$

O comentador localiza o ente humano, como se vê acima, em um meiotermo entre os radicais autenticidade e inautenticidade. O ente humano está como tensão entre as duas possibilidades existenciais, de modo que não é possível ser puramente um ou outro.

Além disso, segundo Heidegger, o Dasein, em ambos os modos, é compreensão [Verstehen]. Compreensão, neste caso, indica um sentido de familiaridade originária com o mundo (condição pré-reflexiva e pré-teórica), quer dizer, uma pré-compreensão de ser na qual o ser ainda não é tematizado ${ }^{48}$.

\footnotetext{
${ }^{45}$ Charles Guignon, Heidegger and the problem of knowledge, 1983, p. 43.

${ }^{46}$ Michael Inwood, Heidegger, 2004, p. 37-38.

${ }^{47}$ Jean-Paul Resweber, O Pensamento de Martin Heidegger, 1979, p. 98, grifo nosso.

${ }^{48} \mathrm{Na}$ verdade, compreensão enquanto campo teórico (esclarecimento), próprio do âmbito cognitivo, é uma derivação existencial do sentido mais originário e primário de compreensão que
} 
Assim, compreender indica saber-como-ser, indica saber-prático em lidar com o próprio ser. "A compreensão deve ser entendida primordialmente como poderser do Dasein"49, nesse sentido afirmar que o Dasein "é" poder-ser é o mesmo que poder-ser-no-mundo. Isso significa que o Dasein "é" tudo aquilo que ele pode ser, tudo aquilo que ele não pode ser e o modo como pode ser. Dasein "é" poder-ser - o que isso expressa? O "poder" diz capacidade, possibilidade, e o "ser" não indica uma coisa e sim ter de ser, portanto, o poder-ser diz o ser possível. Seguindo o raciocínio: "Na compreensão, o Dasein projeta seu ser para possibilidades"50. Completa-se, então: Dasein "é" poder-ser possibilidade: "Primariamente, ele [Dasein] é possibilidade de ser. Todo Dasein é o que ele pode ser e o modo em que é a sua possibilidade"51. Verifica-se, assim, que o Dasein pode-ser a partir de possibilidades e como possibilidades (possibilidades de ser desta ou daquela maneira).

Isso tudo para sinalizar que mesmo na sua inautenticidade o Dasein é compreensão. Ou seja, ainda que imerso no domínio da impessoalidade, o Dasein coloca em jogo sua abertura compreensiva na existência, de modo que sempre já se compreendeu de alguma forma, mesmo a partir do ponto de vista dos "outros".

o Dasein de fato já se compreende sempre em certas possibilidades existenciárias mesmo que os projetos provenham, meramente, da compreensibilidade do impessoal. Explicitamente ou não, adequadamente ou não, existência é sempre, de algum modo, compreendida. ${ }^{52}$

Vê-se, então, que tanto o poder-ser autêntico em-si-mesmo, quanto o poder-ser inautêntico impróprio, são possibilidades de compreensão do Dasein, nas quais ele pode-ser-no-mundo. Em Ser e tempo os conceitos de autenticidade e inautenticidade indicam modos de ser, no sentido de leque de possibilidades que

indica familiaridade com o mundo - diga-se de passagem, qualquer forma de conhecimento é uma derivação da compreensão enquanto existencial: 'Intuição' e 'pensamento' já são ambos derivados distantes da compreensão" (Heidegger, op. cit., 1988, p. 203). Para Heidegger, compreender é mais originário que interpretar: interpretar é interpretar um mundo já compreendido.

${ }^{49}$ Martin Heidegger, Op. Cit., 1988, p. 226.

${ }^{50}$ Ibidem, p. 204.

${ }^{51}$ Ibidem, p. 199.

${ }^{52}$ Martin Heidegger, op. cit., 2005, p. 105. 
o Dasein pode-ser (dessa ou daquela forma).

Com efeito, a essência do Dasein é a existência - "a substância do homem é a existência"53-, e existir não indica necessariamente existir autenticamente, mas, isto sim, indica o modo de ser. Heidegger escolheu o termo existência [Existenz], em seu sentido original: "existência" resulta da preposição ek e do verbo sistere, que significa "estar para fora", movimento que parte de dentro para fora, ek-sistir diz respeito ao estar/projetar-se para fora, para a exterioridade, expandir para fora. Ernildo Stein em Introdução ao pensamento de Martin Heidegger, observa: "Como existência - ek sistere - o homem já está sempre projetado para frente, sempre se antecipa" ${ }^{n 4}$. E justamente por essa razão que o ente que nós mesmos somos é o único ente que ek-siste, diferente dos entes desprovidos da estrutura de ser-no-mundo que "são" mas não existem, conforme corrobora André Dartigues: "[...] o homem é o único Eksistente, o único questionador entre os outros entes dos quais podemos dizer que são, mas não que existem. É a razão pela qual só o homem vivo e concreto poderá ser chamado Dasein" 55 .

Assim sendo, uma existência inautêntica não corresponde a uma existência menor, mas sim a um modo de ek-sistir. É neste sentido que Heidegger, em Ser e tempo, coloca fundamentalmente em questão como é o ser e não o que é o ser, diferenciando-se radicalmente dos filósofos da tradição que se debruçaram sobre o ser. Abordando-o enquanto modalidade existencial e não categorial, o filósofo alemão procura no ser do ente humano não mais uma essência fixa, mas sim seus possíveis modos de ser em termos de possibilidades existenciais do seraí humano.

Em vista disso, quando Heidegger traz à tona a existência inautêntica e a existência autêntica, ele está tão somente destacando os dois modos fundamentais do existir humano. Heidegger não distingue os dois modos

\footnotetext{
${ }^{53}$ Martin Heidegger, Op. Cit., 1988, p. 279-280.

${ }^{54}$ Ernildo Stein, Introdução ao pensamento de Martin Heidegger, 2011, p. 30.

55 André Dartigues, O que é a Fenomenologia?, 1992, p. 130.
} 
fundamentais de ser-no-mundo em termos de valorar moralmente um em detrimento do outro.

Ademais, ser-no-mundo - mesmo inautêntico - é, em essência, cuidado [Sorge]. Cuidado, segundo Heidegger, diz respeito a uma interação cuidadosa do Dasein com seu próprio ser: nota-se, portanto, que o Dasein nunca está irrecuperavelmente perdido na inautenticidade. Lançar uma projeção existencial sobre o ser, abrindo-o deficientemente - isto é, não se apoderando de si mesmo, portanto, perdendo-se de si mesmo -, não significa que não se tenha mais cuidado sobre o ser. O cuidado é o núcleo mais elementar e mais primário do Dasein, e por isso mesmo é a totalidade ontológica mais elementar: "a cura se acha, do ponto de vista existencial, a priori, 'antes' de toda 'atitude' e 'situação' do Dasein, o que sempre significa dizer que ela se acha em toda atitude e situação de fato"56. O cuidado é a fonte ontológica mais originária a partir da qual surgem os variados modos de ser do Dasein, e neste sentido a inautenticidade não extingue ou exclui o cuidado. Segundo Heidegger, o ente humano "possui a 'origem' de seu ser na cura"57, e permanecerá ligado a essa origem enquanto for e estiver no mundo, quer dizer: se o Dasein cessasse completamente de se importar e interagir cuidadosamente com o seu ser, ele cessaria de ser Daisein, uma vez que deixaria de ser cuidado.

Quando usamos, a partir de Ser e tempo, o termo "cuidado" já nos referimos à ocupação [Bersogen] e preocupação [Fürsorge] do Dasein (trata-se de uma cura ocupada-preocupada, besorgend-fürsorgende Sorge). Quer dizer, o termo contempla não apenas as relações que o Dasein trava com o modo de ser dos entes simplesmente dados, mas, também, contempla relações em que há consideração [Rücksicht], consideração em termos de contínuo cuidar ("prático"). Com isso, procurou-se ressaltar que o Dasein, ainda que perdido de si mesmo, não se acha irremediavelmente no modo inautêntico, visto que possui como estrutura mais

\footnotetext{
${ }^{56}$ Martin Heidegger, Op. Cit., 1988, p. 258.

${ }^{57}$ Ibidem, p. 264.
} 
originária e primária a relação cuidosa com seu ser.

\section{Considerações finais}

Diferente de como poderíamos crer em uma primeira e sumária leitura de Ser e tempo, autenticidade e inautenticidade do Dasein não estão na condição de existência "superior" existência "inferior", no sentido de que uma é "melhor" que a outra. Autenticidade e inautenticidade não equivalem exatamente a existir, mas, isto sim, ao modo de existir.

A inautenticidade de ser-no-mundo está relacionada com a decadência, cujo sentido indica que, de início e na maioria das vezes, o Dasein perde-se de si mesmo ao se afundar na ocupação. Quer dizer, o Dasein caiu de si mesmo e decaiu no mundo das ocupações e passa a compreender a si mesmo (o mundo e aos outros) em função apenas destas ocupações. Por outro lado, a inautenticidade de ser-no-mundo está intimamente implicada no sentido heideggeriano de publicidade do impessoal (cujos elementos característicos são falatório, curiosidade e ambiguidade). Nela, a possibilidade de ser-próprio do Dasein é tomada pelos "outros", na medida em que se dá o domínio da impessoalidade. O impessoal, quer dizer, os "outros", retira do ser-no-mundo a responsabilidade de ter que assumir seu próprio ser. O Dasein não é ele próprio e sim os outros que lhe tomam o ser.

Em vista disso, vale ressaltar que Heidegger não procura hierarquizar o poder-ser inautêntico e o poder-ser autêntico. Na verdade, os dois conceitos em questão dizem respeito aos modos de ser-no-mundo: um modo em que o Dasein se perde no impessoal, e outro no qual ele se coloca diante de seu poder-ser-simesmo. Destaca-se que a existência inautêntica não corresponde a uma existência "menor", mas sim a um modo de ek-sistir. O modo de ser inautêntico do ser-aí, neste sentido, não é valorado pelo filósofo alemão como o "mal" do qual devemos escapar - e tampouco a autenticidade está como bem para o qual 
devemos tender -, antes, porém, trata-se de uma possibilidade de ser-no-mundo, na qual o Dasein ainda tem compreensão [Verstehen]. Além disso, o Dasein nunca está irrecuperavelmente perdido na inautenticidade, pois, em última instância, o ser-no-mundo - mesmo inautêntico - é, em essência, cuidado. Ou seja: ele possui como estrutura mais originária e primária a relação cuidadosa com seu ser.

\section{Referências}

CASANOVA, Marco. Compreender Heidegger. Petrópolis, RJ: Vozes, 2009;

DARTIGUES, André. O que é a Fenomenologia? 3 ed. Trad. Maria José J. G. de Alemida. São Paulo: Editora Moraes, 1992

FIGAL, Günter. Martin Heidegger: fenomenologia da liberdade. Trad. Marco Antônio Casanova. Rio de Janeiro: Forense Universitária, 2005.

GUIGNON, Charles. Heidegger and the problem of knowledge. Indianapolis, Indiana: Hackett, 1983.

HEIDEGGER, Martin. Being and Time. Trad. J. Macquarrie e E. Robinson. São Francisco: Harper, 1962.

. Ser e Tempo - parte I. Trad. Márcia de Sá Cavalcanti. 2 ed. Petrópolis: Vozes, 1988.

Ser e Tempo - parte II. Trad. Marcia Sá Cavalcante Schuback. 12 ed. Petrópolis: Vozes, 2005.

. Ser y Tiempo. Trad. Jorge Eduardo Rivera. Santiago del Chile: Editorial Universitaria, S.A., 1997a.

. O Conceito de tempo. Cadernos de Tradução, v. 1, n. 2, p. inicial-final, DF/USP, 1997b. 
INWOOD, Michael. Dicionário Heidegger. Trad. Luísa Buarque de Holanda. Rio de Janeiro: Jorge Zahar, 2002.

. Heidegger. São Paulo: Loyola, 2004.

MORAN, Dermot. Introduction to phenomenology. London and New York:

Routledge, 2000.

RESWEBER, Jean-Paul. O Pensamento de Martin Heidegger. Trad. João

Agostinho A. Santos. Coimbra: Livraria Almedina, 1979.

SAFRANSKI, Rüdiger. Heidegger - um mestre da Alemanha entre o bem e o mal.

Trad. Lya Luft. São Paulo: Geração Editorial, 2000.

STEGMÜLLER, Wolfgang. A filosofia contemporânea: introdução crítica. São

Paulo: EPU, 1977.

STEIN, Ernildo. Introdução ao pensamento de Martin Heidegger. Porto Alegre: EDIPUCRS, 2011.

Referência para citação deste artigo

ALMEIDA, Rafael; TOLFO, Rogério. O conceito de inautenticidade no pensamento heideggeriano de Ser e tempo. Revista PHILIA | Filosofia, Literatura \& Arte, Porto Alegre, volume 1, número 2, p. 461 - 483, outubro de 2019. 